Article received on 3rd November 2015

Article accepted on 16th November 2015

UDC: 789.983 .087 .682

COBISS.SR-ID 223352844

\author{
Adriana Sabo* \\ University of Arts in Belgrade \\ Faculty of Music \\ $\mathrm{PhD}$ studies of musicology
}

\title{
WOMAN AND/OR WATER: WHO IS SVETLANA SAVIĆ'S TRAPPED? ${ }^{1}$
}

\begin{abstract}
Svetlana Savić was given the "Mokranjac" award for her composition titled Trapped (2014), written for female choir and electronics. Originally composed for a multimedia project realized by the "Collegium Musicum" choir titled Water, Savić's piece was inspired by water trapped inside pipes, a subject that enabled her to realize the musical flow using a variety of murmurs and noises, as well as to expand upon the numerous possibilities offered by the contrast between a female voice and electronically produced sounds. The musical language of Trapped can thus be understood as the result of research into the possibilities offered by the sonic traits of the musical material, the relationship between consonant and dissonant intervals - mostly seconds and thirds - and as a very compact, yet incredibly expressive musical manifestation of feelings of captivity and fear of drowning.
\end{abstract}

Key Words: Trapped, Svetlana Savić, "Mokranjac" award, water, expression

The "Mokranjac" award for 2014 was given to Svetlana Savić, for a composition titled Trapped (for female choir and electronics). Trapped is, to be precise,

\footnotetext{
* Author contact information: imeprezime259@gmail.com

1 This research was carried out as part of the scientific project of the Department of Musicology of the Faculty of Music in Belgrade Identiteti srpske muzike u svetskom kulturnom kontekstu [Identities of Serbian Music in the World Cultural Context], supported by Ministry of Education, Science and Technological Development of the Republic of Serbia.
} 
only one movement of a larger vocal-instrumental piece commissioned by the "Collegium Musicum" choir, ${ }^{2}$ that consisted of five segments, each one composed by one author - Tatjana Milošević, Branka Popović, Svetlana Savić, Ivan Brkljačić and Draško Adžić. The underlying theme of each movement was water and each one was composed on a text written by Vanja Nikolić. Savić described her compositional process in the following words:

We agreed that our compositions should describe the journey of a drop of water from ice, via clouds, lakes and pipes to a faucet in a tavern. We all chose our field and I got water trapped inside a piping system, because Dragana [Jovanović. Author's note] and Vanja Nikolić (who wrote the screen play and the libretto) thought that this movement should include electronics. ${ }^{3}$

Trapped was composed during the floods of May 2014, which strongly influenced the final look of the piece. Writing about her compositional process, Savić especially emphasizes the feeling of suffocation in her "own fear of drowning", adding that "in those days, horror entered in [her] music."4

In the opus of Svetlana Savić, we can note a few constants, among which one should emphasize her inclination towards the female voice - whether as a solo voice or as a female choir - and her interest in the examination of different sounds and acoustic spaces that open up due to use of (artificial) electronics and their "dialogue" with the (natural) female voice. ${ }^{5}$ In the case of Trapped, the juxtaposition between the sound of the female choir and the electronically modified sounds of the author's own breath and sighs is especially interesting, as they draw one's attention again towards the relationship between the "natural" and the "artificial", the live sound and the recorded one, music and noise. The composition is, it should be noted, very short and concise, yet never simple. It contains six segments and the musical flow is made to describe the sense of drowning. Its

2 Its premiere was held in 2014 and was a part of the multimedia project titled Water.

${ }^{3}$ Quoted after Savić's commentary of the composition, given to the jury of the "Mokranjac" award. Author's own translation.

4 Ibid.

5 Another work in which Savić focuses on the mentioned relationship is titled Sonnets (2008-2011) and is also composed for a female voice, accompanied by cello, piano and electronics. This piece was composed as her doctoral artistic project and it was reviewed in the section "New works" of this magazine. Cf. Branka Popoić, "Svetlana Savić: Soneti 'La Douce Nuit', 'Looking On Darkness', 'La Vita Fugge'”, in: New Sound - International Journal of Music 44, II/2014, 157-172. The composer's interest in the female voice is also evident in such works as Sirota, tužna Don Huanova kći for soloists, female choir and electronics, (1992) and Pesme o zvezdama for female choir and chamber orchestra. cf: Милан Михајловић, “Песме о звездама Светлане Кресић”, Нови звук - интерначионални часопис за музику, бр. 18, 2001, 79-84. 
form is circular, as the material from the beginning - realized through the use of electronic sounds - is repeated at the end, which is a procedure that additionally emphasizes the sense of being trapped and moving in circles. In other words, the inside segments, dominated by the female choir are surrounded by concrete and electronically modified sounds and noises. ${ }^{6}$

Another characteristic trait of this work is the "instrumentation", as the score - other than the parts written for the choir - also introduces parts for water, pipes, breathing and morph voices, ${ }^{7}$ gurgles, etc. (see Example 1). Thus, other than female voices, the musical flow is made of sounds of breathing - more precisely defined with terms such as "gaspingly" (bar No. 9), "while running" (bar No. 14), or "inhale - exhale" (bar No. 16) - a water pump (bar No. 20), a faucet (bar No. 26), those labeled as "flying noise" (bar No. 32, in the part designated as "breathing 1"), "glissando machine" (bar No. 34, in the part of water and pipes), sounds of drops, strokes, blowing in a bottle (see Example 1), as well as sampled sounds of the piano, glockenspiel, lute and percussion, (see Example 4). In other words, the electronic segment of the composition reveals the author's wish to examine the sonic possibilities offered by the sounds of water (and its different states) and at the same time, to describe the sense of drowning and the horror that follows it, precisely by working with sonic similarities between the sound of running water and that of a human breath.

The female choir that interprets, so to say, the role of the one who is trapped (water and a woman) is in constant "dialogue" with electronic sounds realized in the already described way. The text that is sung is based on repetition:

Pressed. Bound. Strained. Restrained. Trapped. Clenched.

To pain. To the core.

Pressed. Bound. Strained. Restrained. Trapped. Clenched.

To pain. To tears.

Pressed. Bound. Strained. Restrained. Trapped. Clenched.

I hate.

Pressed. Bound. Strained. Restrained. Trapped. Clenched.

Not to move.

6 The musical flow of Trapped can be segmented in the following way: I section, bars 1-20; II section, bars 20 - 28; III section: bars 29-34; IV section, bars 35-44; V section, bars $44-$ 62; VI section, bars $62-75$.

7 These are electronically generated sounds that act as a chord-like base and, as opposed to other electronic "roles", have fixed pitches. 
Pressed. Bound. Strained. Restrained. Trapped. Clenched.

Not to pour out.

Pressed. Bound. Strained. Restrained. Trapped. Clenched. ${ }^{8}$

The text is, thus, envisioned as a segmented flow of words that describe the sense of helplessness and fear, while a similar procedure is used by the composer in the process of creating the music for Trapped. Words are syllabic, pronounced at the same time and in the same rhythm by each voice in the choir. The choir sings these words separately at first, with pauses between the words, (see Example 3), and afterwards, in "a single breath", which is a very useful technique used to build a culmination that begins in bar No. 44 and lasts until bar 62 (see Example 4). The music that is sung is dominated by seconds that can be understood in light of the musical conventions used to describe fear, helplessness and pain, but they are also an interval that has great importance for the poetics of Svetlana Savić. Namely, when writing about her composition Songs About Stars for a female choir and chamber orchestra (2001), she states that they (songs) reveal "an ever present fascination with the research of the phenomenon of consonant and dissonant intervals with all their inter-states and layers," adding that this piece can be understood as an "extensive study about the second," 10 and emphasizing the importance of this interval for her poetics. In a similar manner, one can describe Trapped as a study in the process of relating consonant and dissonant intervals, as well as concrete/electronic sounds. It should also be emphasized that the whole of the piece's musical flow is derived from the "buzzing" of a second that is introduced at the beginning, while the melodic parts of the voices in the choir - as well as their mutual relationships - are based on the principle of varying this "basic" interval.

When it comes to the author's relation towards the qualities of the sounds that she uses, it should be emphasized again that Trapped is an example of the musical juxtaposition between the "natural" sounds of a female voice and the "artificial" sounds of electronics, whose potential was used as a very creative compositional tool. Namely, even though these elements of the work are clearly separated in the first and last segment of the piece, they are uniquely combined

8 The original text in Serbian is: Stisnuta. Vezana. Sapeta. Sputana. Zarobljena. Stegnuta/Do boli. Do srži./Vezana. Sapeta. Sputana. Zarobljena. Stegnuta. Stisnuta./Do besa. Do plača./Sapeta. Sputana. Zarobljena. Stegnuta. Stisnuta. Vezana./Mrzim./Sputana. Zarobljena. Stegnuta. Stisnuta. Vezana. Sapeta./Da ne krenem./Zarobljena. Stegnuta. Stisnuta. Vezana. Sapeta. Sputana./Da ne poteknem./Stegnuta. Stisnuta. Vezana. Sapeta. Sputana. Zarobljena.

9 Светлана Кресић, “Песме о звездама”, Нови звук - интернационални часопис за музику, бр. 18, 2001, 85-87. Author's own translation.

10 Ibid. 
and intersected in its central parts. For example, the initial part of the composition ends with the entrance of the sopranos in a high register, singing the letter "a" on e\#", $\mathrm{f}^{2}$ and $\mathrm{g}^{2}$. This dissonant chord is comprised out of three major seconds, clearly contrasting the earlier musical flow that was composed primarily out of noises, but sounding, at the same time, "cold" and even "artificial", simultaneously fitting into the "electronic surroundings" and announcing the segments that are to come (see Example 4). Another interesting example of the interaction between the voice and the electronics comes in bar 38, and is later repeated in bars 41 and 44: at these points, one notices a great similarity between the sounding of the choir and the parts of the piano and glockenspiel and lute (see Example 4). Namely, the similarity is achieved due to the fast, upward and chromatic movement of the altos that sing the words "Bound. Strained. Restrained. Trapped," and the glissando that first appears in the part of the piano, followed by the one in the part of the glockenspiel and lute (whose sounds are sampled and electronically modified). Thus, it can be said that the sound of this segment is directed towards describing the sense of rage and hatred because of constraint, while such "sonic aggression" is complemented by the sounds of breathing, of pipes and machines, etc.

The already mentioned composer's preoccupation with consonant and dissonant intervals and their relations can be observed in the sections sang by the choir as well. Each vocal part is dominated by swift "exchanges" between seconds and thirds, which is a procedure that results in a musical flow that being dominated by chromaticism. The minimal movement in the melodic line also produces the impression that the entire piece is vibrating, evoking in this way the sound of the hissing, dripping or murmuring of water. As can be seen in Example 3, both the horizontal and the vertical lines of the piece are carefully composed to present a number of possible relationships between the consonant and dissonant intervals.

The given examples also point to the fact that repetition plays a vital role in the compositional process Svetlana Savić used in this piece. This is why it is important to further examine the rhythm that, on the one hand, adds to the sense of constant movement due to the constant shifting between the sixteenth and eighth notes, tuplets and dotted notes, while on the other, due to its repetitiveness, it produces the sensation of trapped water moving in circles. The anger and frustration that comes from this kind of movement is also enhanced by the way the sung text sounds. Namely, its author used a number of words that contain "sharp" consonants such as $\mathrm{r}, \mathrm{z}$ or $\mathrm{s}$ that, when sung by a choir, add to the sound of hissing water and the noises present in the electronic part."

${ }^{11}$ Here, I have in mind words like "stisnuta", "vezana", "srži”, "mrzim" etc. See fn.8 for reference. 
Trapped by Svetlana Savić can also (re)open a debate concerning the existence of female writing in music. Namely, as the composer herself pointed out, in this case water is understood as a woman, which was one of the reasons she decided to include recorded sounds of her own breathing and whispering into the musical flow of the composition. In other words, Trapped invites the listener to (re)think about the understanding that suffering, imprisonment and weakness are "typically" female traits - which is a theme often referred to by such female writers as Virginia Woolf. ${ }^{12}$ However, Svetlana Savić's composition cannot be understood as an example of female writing, at least not in the way this concept was introduced by French theoreticians such as Hélène Cixous. ${ }^{13}$ Namely, female writing means that a work of art is the result of the artist's intention to question her own position in society and to introduce her own body into her poetics, thus inventing her own, unique means of artistic expression that would be the result of her body being inscribed into her work. As Cixous wrote, a woman "physically materializes what she's thinking; she signifies it with her body." 14 Female writing, thus, emphasizes the necessity of introducing the "authentically" female corporeality into the artistic expression that has, for the most part, negated its existence. In other words, this concept can be understood as an act through which women strive to "redefine their own identity that was understood primarily through their sexuality, thus opening the possibility of self-definition." ${ }^{15} \mathrm{Or}$, as Cixous points out, female writing emphasizes the fact that "women must write through their bodies, they must invent the impregnable language that will wreck partitions, classes, and rhetorics, regulations and codes." 16 Thus, the concept is, in its essence, based in activism, envisioned as a mechanism that gives women a tool for making some radical interventions into reality. It questions the idea of art being autonomous from the society and gives it the possibility to be political and offer social criticism.

Even though Trapped undoubtedly shows the composer's personal relation towards the given subject, it cannot be said that it represents her intention to cre-

\footnotetext{
12 For instance, the subject of female "captivity" are addressed in novels like "A Room of One's Own" or "Mrs Dalloway".

13 Trapped could be understood as a "female" composition solely based on the fact that it was created and realized by women, which is not a sufficient reason for a work of art to be labeled as female writing.

14 Hélène Cixous, "The Laugh of the Medusa", in: Signs Vol. 1, No. 4, 1976, 881.

15 Ivana, Velimirac, “Žene i književnost”, u Adriana Zaharijević (prir.), Neko je rekao feminizam? Kako je feminizam uticao na žene XXI veka, Beograd: Žene u crnom, Centar za ženske studije, Rekonstrukcija ženski fond, 2007, 265.

16 Hélène Cixous, ibid, 886.
} 
ate her own, authentic compositional language that would be based on specific traits of her corporeality or sexuality. Also, even though Savić did introduce her own body into the musical flow - using recordings of her breathing, whispering, etc. - this act cannot be understood as an attempt to question the place of her own (female) body within the patriarchal system in which she lives. Namely, the composer's voice was - due to the electronic medium and the possibilities for sound alterations it offers - "lifted" to the universal plane and the voice of Svetlana Savić became, so to say, the voice of a universal Woman, Water, and/or the one who is trapped. The fact that the sounds of the composer's body are often radically changed so that they cannot be recognized and that their reproduction is left to the conductor/conductress - they were separated from the composer and made to be universal - further support the claim that Trapped cannot be understood as an example of female writing in music. Additionally, the described tension between the consonant and dissonant intervals, between the "natural" female voice and the "artificial" noises can also be understood as an attempt to "give sound" to the tension between the possible meanings present in the composition, that is, to a kind of duality of the one who is trapped - she is both a woman and water. It should also be noted that the connection Savić establishes between a woman and water does not stem solely from the fact that in the Serbian language, "water" is a word in the feminine gender. The act of bringing together these two "concepts" can, namely, be understood in light of the centuriesold artistic concepts that view women and water as similar "beings", forces of nature that have the ability to give life, to cure and cleanse, objects/subjects that can be graceful, elegant and mysterious.

With these ideas in mind, one can draw certain analogies between Trapped and a composition titled She for voice, flute, violoncello, piano and a clock (2008) by Ivana Stefanović that also focuses on the question of female "captivity" understood, of course, in a different way. Namely, She is composed on segments of Ljubomir Simović's drama titled Hasanaginica that are used in order to describe the absurdity of the life of a bourgeois woman who is, in a traditional society, bound to the house and daunting repetitive tasks. The female voice in this composition repeats the following words: "folded, arranged the dresses, wrapped the handkerchiefs, earrings, counted the rings, necklaces; you put here, relocate, unwrap, re-wrap, you take and leave, you begin and undo, begin again...", ${ }^{17}$ describing in this way the boring everyday life of a woman whose "place is at home". As Stefanović wrote in her note about the composition, "She

17 The original text in Serbian is: "savila, složila haljine, uvila rupce, minđuše, izbrojala prstenje, ogrlice; staviš ovde, premestiš, odmotaš, zamotaš, uzmeš ostaviš, prepočneš pa oparaš, započneš...” 
is envisioned as an illuminated, frozen moment, the moment of a strong inner pain. Should I say emphasize, female?"18 In other words, Stefanović chose to present the image of a universal Woman, any and every woman, since, through the interventions in the text of Simović's drama, she removed all traits that are typical of Hasanaginica and her unique fate. But, in this case, the universalized woman is, in fact, a member of the upper class, a woman who possesses jewelry and dresses, and who is placed inside the home by society and given the role of a homemaker. She is, in other words, unemployed, confined to completing such (easy) tasks as doing embroidery and is kept away from any kind of physical labor. In other words, the universalized Woman in this case is the one whose father/husband has a certain amount of social power and not a member of the working class, a peasant woman, a prostitute, etc. Of course, in the case of Svetlana Savić's work, there is no reference to the life of a specific woman, but both compositions rest upon the notion that the sense of being trapped is universal: it is at the same time a universally human feeling and, at the same time, is inseparable from the universal Female subject. Among other similarities, one finds the repetitiveness of the musical flow and the inclination towards using different expressive means offered by the female voice - not only singing but sighing, whispering, etc.

In the end, it should be pointed out that Trapped offers another possible analogy, namely, with the sound world of Ljubica Marić, one of the first female composers who was "accepted" into the canon of Serbian classical music but who never questioned her social standing through her music - which is, also, one of the important indicators of the status women had in the SFRY. The fact that Marić's artistic output lacks a critical view of her own artistic and social position - as a woman who works in a field dominated by men - points, on the one hand to the strength of modernist ideas about the autonomy of music that is, as such, "free" from social happenings as well as from the gender of the one who creates it and, on the other hand, reveals the fact that the gender (male or female) of a composer was never brought into question since this area was undoubtedly reserved for men and there was nothing questionable about that. In this sense, the relationship of Svetlana Savic towards the female subject can be understood in light of the similar, unproblematic position, since that should be, however, understood differently. Namely, the reason gender is once again unproblematic for those who "inhabit" Serbia's world of music can be found (among other places) in the fact that there are a lot of female composers in this country and, thus, Savić's own gender (that is, the fact that she is a female composer) is not in any way strange or problematic. In other words, it would seem that, due to the fact

$18 \mathrm{http}: / /$ composers.rs/?page_id=4503. 
that women composers "conquered" the Serbian world of classical music, Savić did not feel the need to question her own place within this system - especially since she holds the strong institutional position of a professor of composition at the Faculty of Music in Belgrade.

Even though her poetics, as well as the context in which she works is very different from that in which Ljubica Marić lived and worked, one can still notice some similarities between the musical language of these two composers, as well - first of all in the preoccupation with the acoustic quality of the musical material, as well as of the words sung by the choir/soloists, and in the minimalist approach towards that very material, since both composers have the ability to develop the entire musical flow from a small nucleus (the second, for example).

Trapped can, thus, be understood as a result of the composer's intention to create a very short, yet highly complex study in acoustics. This kind of research into the field of sound and the possibilities offered by female voices and electronics are, in this case, clearly directed towards an extra-musical idea. In other words, basically modernist ideas about the autonomy of music were used in order to describe something outside music itself - namely, the sensations of captivity, drowning and fear - which can be understood as one of the constant traits of Savić's opus. ${ }^{19}$ Due to the fact that she identified water as being female, the composer also opened up the possibility of thinking about the place of women in (Serbian) society and produced a masterful musical interpretation of an emotion that can, without doubt, be understood as universally human.

Translated by the author

${ }^{19}$ Cf. Branka Popović, Ibid. 
Example 1. Svetlana Savić, Trapped, bars 1-13.

Zarobljena

za Żenski hor i elektronikt

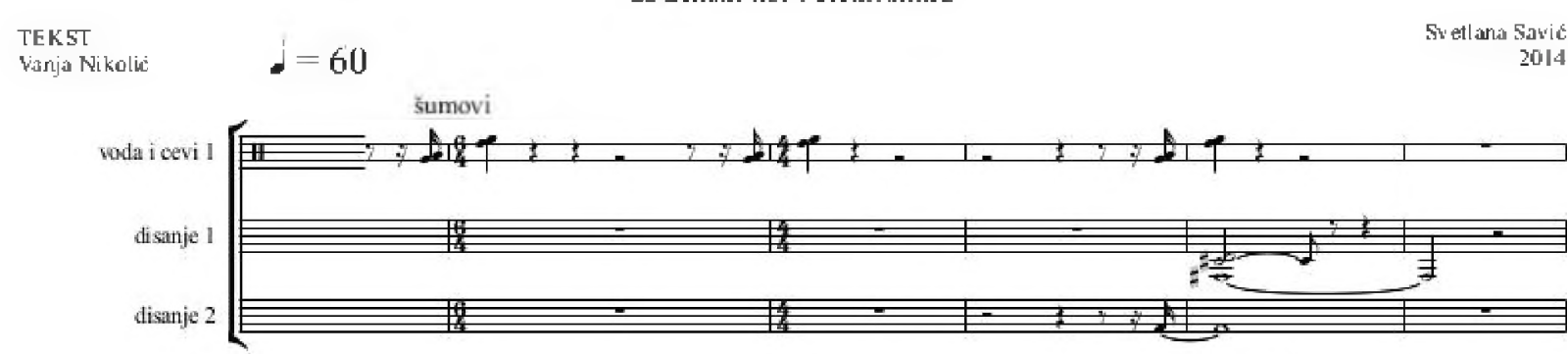

$0: 14$

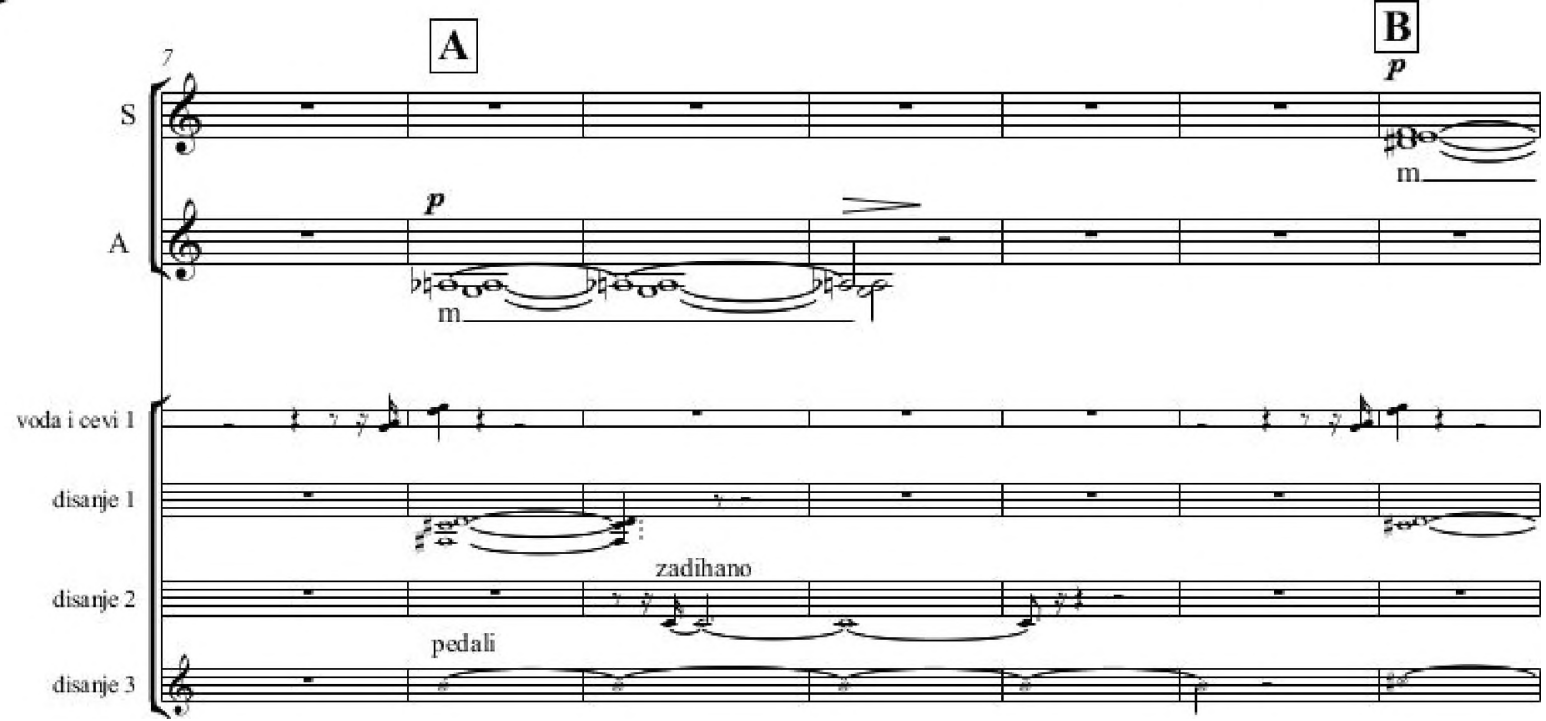

Example 2. Svetlana Savić, Trapped, bars 20-22.

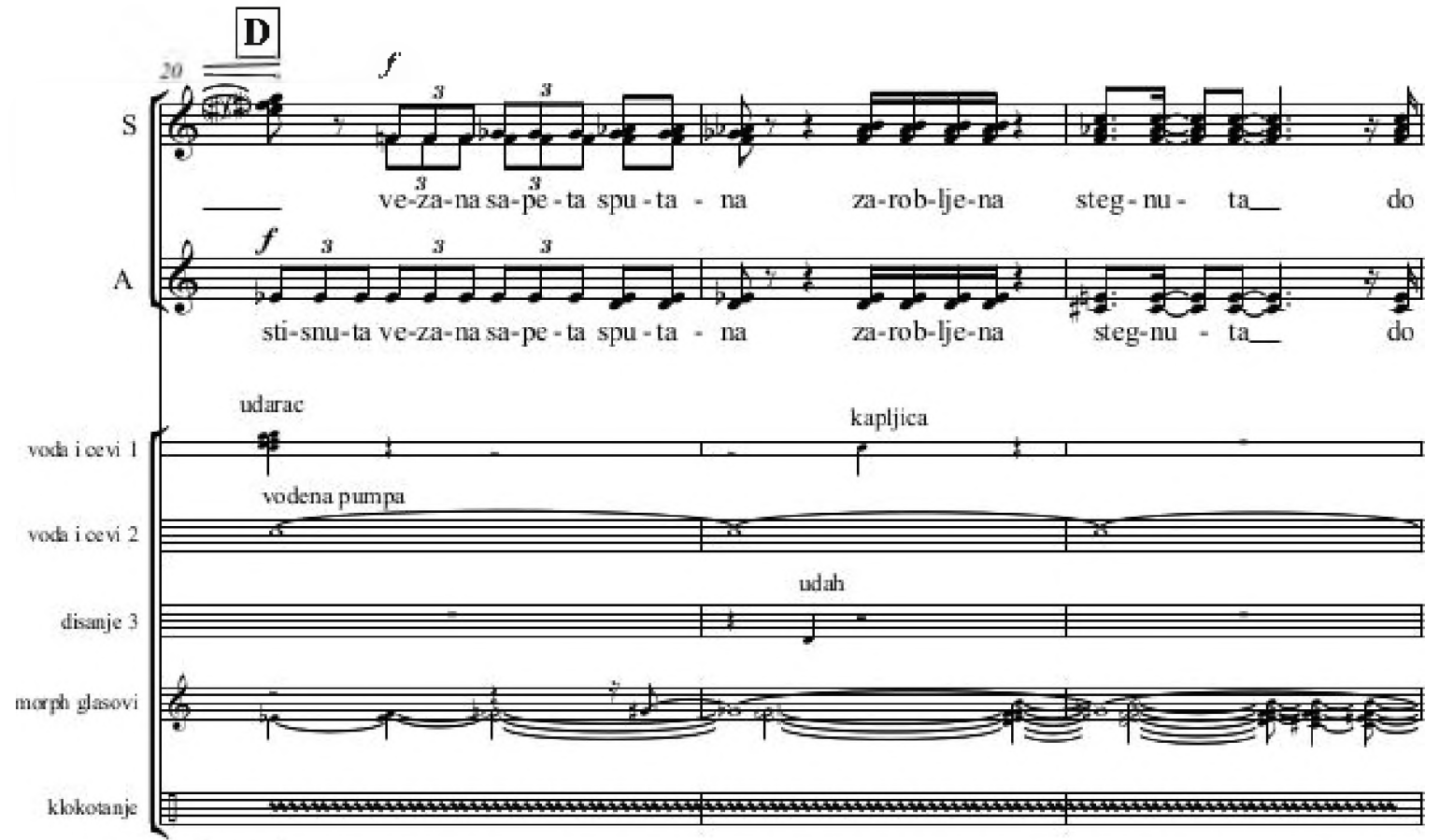

1:14 
Example 2, continued, Svetlana Savić, Trapped, bars 23-25.

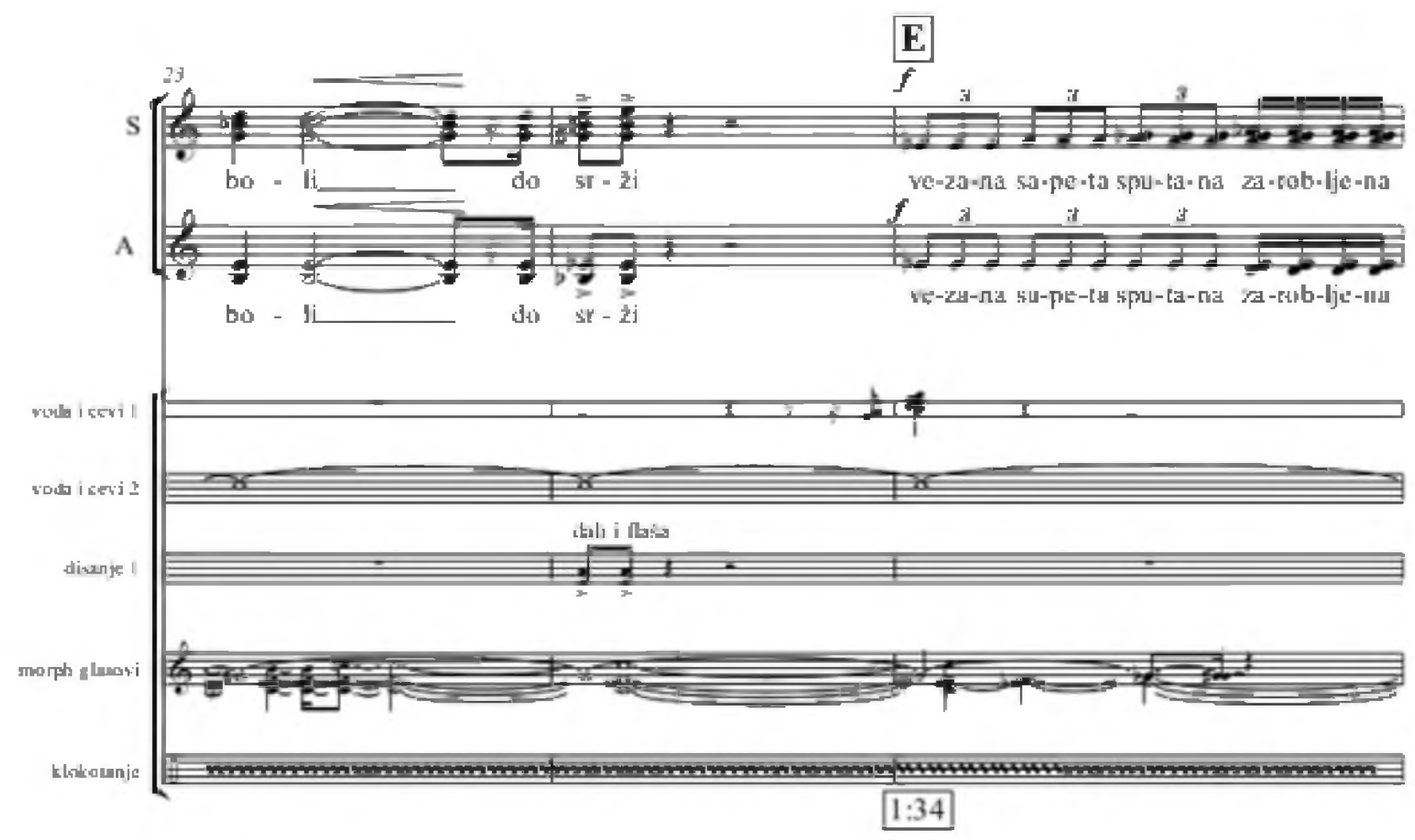

Example 3, Svetlana Savić, Svetlana Savić, Trapped, bars 14-19.

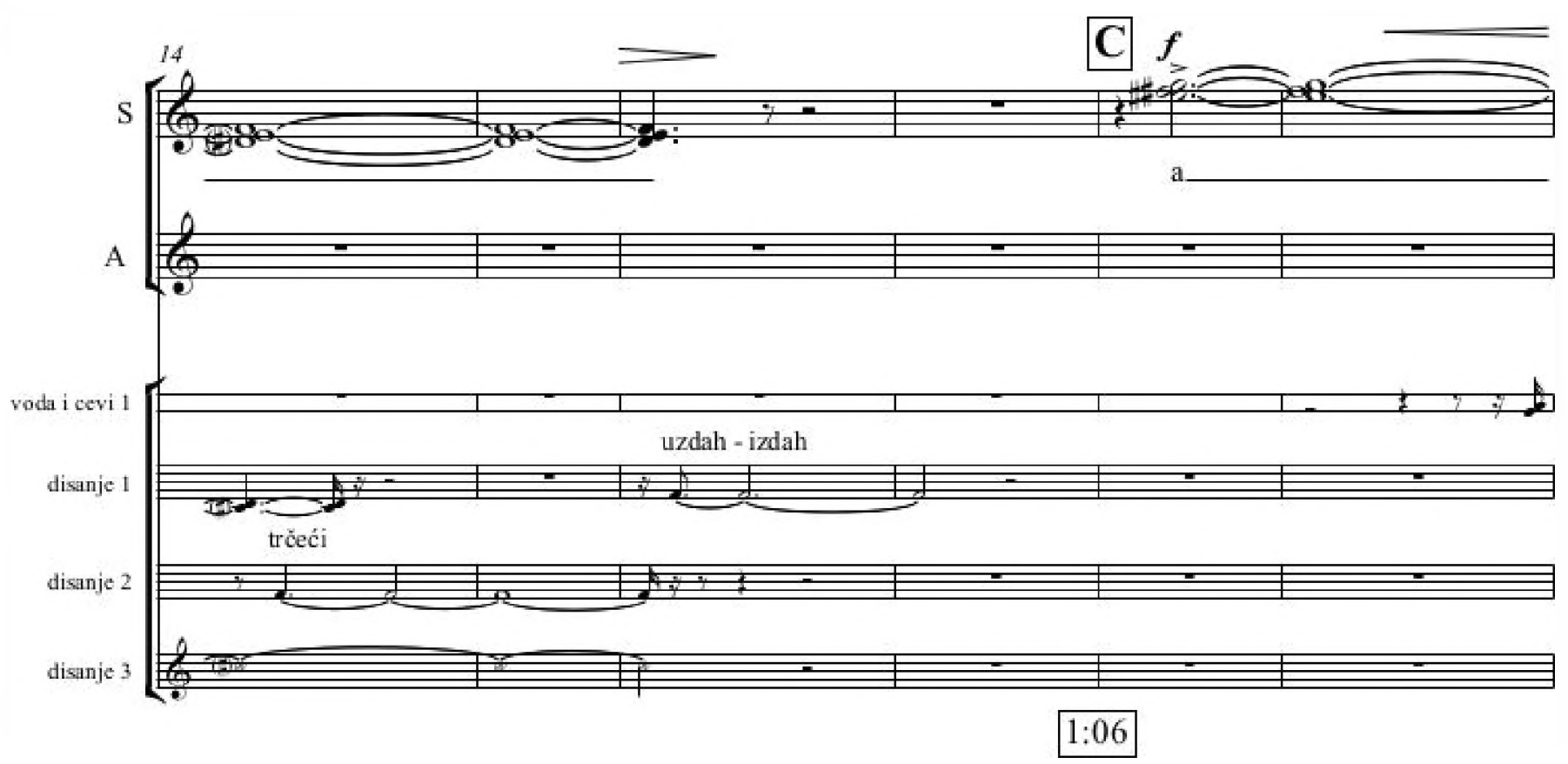


Example 4. Svetlana Savić, Trapped, beginning of the culmination, bars 44-45.

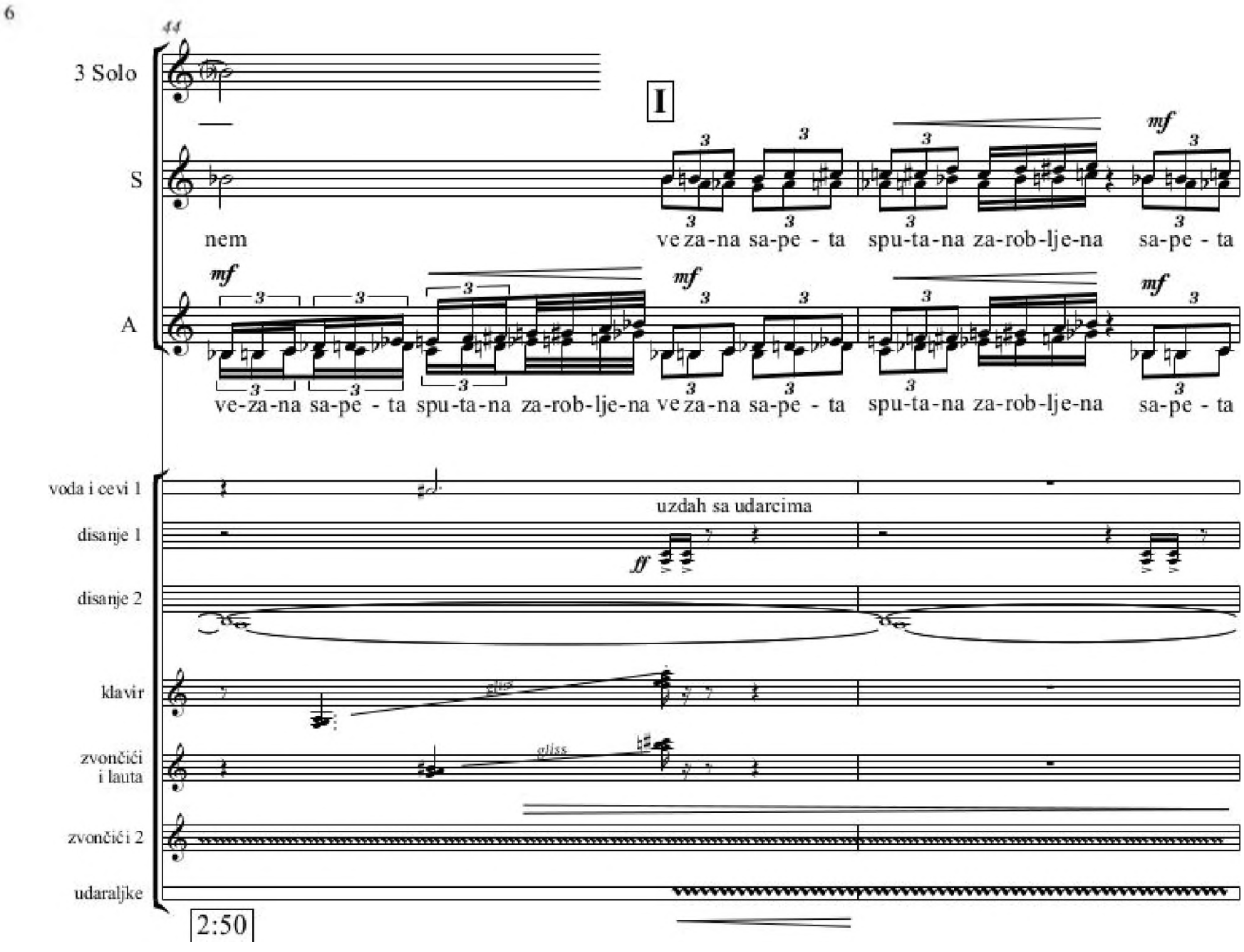

